\title{
Ambitiös avhandling om erotiska möten mellan människa och väsen
}

Harjunen, Catarina. 2020. Att dansa med de(t) skeva: Erotiska möten mellan människa och naturväsen i finlandssvenska folksägner. Avhandling. Åbo, Finland: Åbo Akademi Förlag. (230 sidor)

Catarina harjunens avhandling i folkloristik vid Åbo akademi, $A t t$ dansa med de(t) skeva, har som syfte att genom en undersökning av "finlandssvenska folksägner om människans erotiska möten med naturväsen [...] granska konstruktionen av det så kallat normala i de föreställningar om sexualitet, kön och genus som uttrycks i sägnerna” samt hur dessa konstruktioner kan relateras till föreställningar om natur och kultur (2). Materialet är Iı6 sägner ur olika arkiv, som Harjunen analyserar utifrån queerekologiska och posthumanistiska perspektiv. Kunskapsmålen för avhandlingen är dels att "uppmärksamma finlandssvensk erotisk folklore som rönt ringa akademiskt intresse hittills", dels att "skriva fram en icke-heteronormativ närvaro i ett finlandssvenskt traditionsmaterial och därmed öppna för nya sätt att betrakta och beforska normalitet i ett finlandssvenskt kulturarv" (6).

Harjunens projekt är ambitiöst och avhandlingen är överlag välskriven och väldisponerad, undersökningen utförd med stringens och noggrannhet. En av studiens styrkor är Harjunens hantering av frågan om 
temporalitet - en fråga som gör den uppgift hon tagit sig an svårhanterlig. Här finns nämligen inte mindre än tre olika tidsskikt att förhålla sig till: den förmoderna tid under vilken berättelserna traderades oralt, åren I866-I950, då materialet samlades in, och nutiden, då ju materialet tolkas av henne själv. Detta är en omständighet som Harjunen hanterar genom att I) aktivera historisk forskning om normer och föreställningar rörande kön och sexualitet i bondesamhället, 2) problematisera arkivens insamlingsmetoder och kategorisering, 3) använda samtida queer- och posthumanistiska teorier för att analysera materialet samt 4) kontinuerligt reflektera över sin egen situering. En del av detta hjul kunde Harjunen förmodligen ha sluppit uppfinna genom att mer flitigt konsultera forskning som behandlat just anakronismens problem. Jag tänker här på till exempel Sara Edenheim och - inte minst - Carolyn Dinshaw, som förvånande nog inte anförs förrän $\mathrm{i}$ avhandlingens slutdiskussion. Överlag fungerar tillvägagångssättet emellertid bra genom hela avhandlingen.

Med detta sagt har jag naturligtvis ändå några invändningar. En av dessa rör vad som kan benämnas som avhandlingens "pratighet", det vill säga dess tendens att en smula överdrivet redogöra för väldigt mycket inom de fält som den skriver in sig i. I den teoretiska redogörelsen i inledningskapitlet anförs vissa tankegångar utförligt utan att relateras till projektet. Till exempel tar redogörelsen för Michel Foucaults syn på disciplinering cirka en och en halv sida $(43-44)$ i anspråk innan den rumphugget avbryts och diskussionen övergår till Sara Ahmed. Ytterligare en konsekvens av Harjunens ambitioner att positionera sig inom ett brett forskningsfält är att även de teoretiska resonemang som sätts i förhållande till undersökningen (vilket är merparten) emellanåt förklaras på en väl grundläggande nivå, såsom i redogörelsen för queerteori och performativitet, vars generella uppkomster och utgångspunkter väl vid det här laget är kända för alla som är det minsta orienterade inom det genusvetenskapliga fältet.

Vidare finns det tillfällen när bredden i de teoretiska perspektiven tecknas på bekostnad av djup. Detta är fallet när det fastslås att det problem som åskådliggörs med Judith Butlers heterosexuella matris är att 
"den utgår ifrån att det endast finns två motsatta kön" (42). Här går det att invända att tvåkönsmodellen bara är en aspekt i det betydligt större problemkomplex som den heterosexuella matrisen synliggör. Ett annat exempel finner vi längre ner på samma sida, då Foucaults tankegångar om makt, sexualitet och diskurser uppges utgöra grunden för Butlers könsteori. Detta är, återigen, en grav förenkling. Butler är förvisso inspirerad av Foucaults maktbegrepp, men minst lika mycket av Jacques Derridas språkteorier, samt, allra mest, av den teoribildning som alltsedan r970-talet ägt rum inom den lesbiska feminismen. Sådana, som jag uppfattar det slarviga, formuleringar ger en förenklad bild av utvecklingen inom de queer- och posthumanistiska fält som Harjunen skriver in sig i och drar något ner förtroendet för hennes inblick i de teorier hon anför som grundläggande för avhandlingens analyser.

Med detta sagt väver Harjunen oftast, med imponerande färdighet, ihop historiska studier som belyser materialet med teorier hämtade från det genusvetenskapliga fältet. Ett gott exempel på detta finns i andra stycket på sidan 42, där Foucault och Butler sätts i relation till både primärmaterialet och till Jonas Frykmans avhandling om horan i bondesamhället. En annan styrka i avhandlingen är den djupgående genomgången av materialet, resulterande i ett omfattande materialkapitel som utmärks av att vara såväl gediget som noggrant genomfört (även om jag här, liksom i andra delar av avhandlingen, skulle ha uppskattat ett något flitigare nyttjande av styckesindelning, för läsarvänlighetens skull). Avhandlingen har dessutom ett för akademisk forskning ovanligt högt underhållningsvärde, samtidigt som den aldrig brister i politisk medvetenhet.

Uppfylls då avhandlingens syfte och kunskapsmål, besvaras dess frågeställningar? Ja, det får vi allt säga att de gör. I avhandlingens slutdiskussion har förvisso det inledningsvis definierade delsyftet att relatera de queera perspektiven till begreppen natur och kultur reducerats till att handla om förståelsen av de naturväsen sägnerna skildrar utifrån Haraways term "sällskapsarter" (206). Detta är en märklig insnävning av vad som faktiskt görs, samtidigt som själva användningen av detta begrepp visar på avhandlingens innovativa, ibland närmast djärva, aspekter. Det 
är en sympatisk ingång att tänka sig att trollet, skogsrået, sjörået och näcken, istället för rena fantasifoster vars inverkan på människors tankevärld, ageranden och rörelser lätt kan viftas bort, är arter med vilka vi människor har sällskap här på jorden. Harjunen tar sitt material och sitt projekt på stort allvar - en inställning som förhoppningsvis kan inspirera till fler framtida studier av förhållandet mellan den mänskliga och icke-mänskliga världen vad gäller kön- och sexualitetsnormer på skilda platser, i olika former av material och i alla tider.

ANN-SOFIE LÖNNGREN SÖDERTÖRNS HÖGSKOLA 